\title{
Managing belief in a hostile world: experiencing gifts of the Spirit at a small Pentecostal Charismatic Church in Pretoria
}

\author{
Jim Pieterse \\ Department of Anthropology and Archaeology, University of Pretoria, Pretoria, South Africa \\ Email: jimmy.pieterse@up.ac.za \\ This article focuses on the infrequency with which "gifts of the Spirit" are experienced during services at a \\ small Pentecostal church in Pretoria, attended mostly by Afrikaans-speaking men who self-identify as \\ homosexual. It aims to shed some light on the ways in which pastors work to shape churchgoers' \\ perceptions of the world, their place in it, as well as how experiences of marginalisation and suffering \\ relate to spirits (and their absence) that are understood to mediate between heaven and earth. I argue \\ that difficulties related to the cultivation of faith, on which relationships with the divine are constructed, \\ frustrate direct experiences of spiritual gifts. I also show that certain steps are taken in this church, with \\ varying degrees of success, to try and render the invisible corporeally present. An analysis of sermons \\ is folded into a broader discussion of spiritual self-fashioning and the roles of technologies of the self \\ within the church in an attempt to provide an inclusive, broad-based analysis of "gifts of the Spirit" in a \\ Pentecostal Charismatic Church (PCC) that engages with religious belief on its own terms.
}

Keywords: anthropology of religion; homosexuality; masculinity; Pentecostalism; sexuality; South Africa

On a cold Sunday evening in July 2014, I made my way up the by then familiar stairs that led to the entrance of a recreational hall in Silverton, South Africa, in which the services of Agallia Ministries ${ }^{1}$ were held. As per usual, Pastor Peter waited at the top of the stairs to welcome congregants. Steeled against the winter chill in a thick, dark blazer, he hugged me and said, "I hope you brought your notebook. I am going to say a lot of things tonight." Eagerly anticipating his sermon, I took a seat towards the back of the five neatly arranged rows of plastic chairs, separated by an aisle. More than 20 of the 30 or so chairs thus arranged were occupied - a relatively good turnout. More people were seated in the front than the back. There were more men than women in attendance, although there was a relatively equal distribution of older and younger as well as economically more and less well-off congregants. On account of the cold, everybody present was wrapped up in jackets, jerseys and scarves.

Once everyone was seated, Pastor Peter walked casually to the front. After a brief praise and worship session, he made good on his promise. He first read a passage from 1 Corinthians 12 (NLT 2007):

[1] Now, dear brothers and sisters, regarding your question about the special abilities the Spirit gives us. I don't want you to misunderstand this. [2] You know that when you were still pagans, you were led astray and swept along in worshiping speechless idols. [3] So I want you to know that no one speaking by the Spirit of God will curse Jesus, and no one can say Jesus is Lord, except by the Holy Spirit. [4] There are different kinds of spiritual gifts, but the same Spirit is the source of them all. [5] There are different kinds of service, but we serve the same Lord. [6] God works in different ways, but it is the same God who does the work in all of us. [7] A spiritual gift is given to each of us so we can help each other. [8] To one person the Spirit gives the ability to give wise advice; to another the same Spirit gives a message of special knowledge. [9] The same Spirit gives great faith to another, and to someone else the one Spirit gives the gift of healing. [10] He gives one person the power to perform miracles, and another the ability to prophesy. He gives someone else the ability to discern whether a message is from the Spirit of God or from another spirit. Still another person is given the ability to speak in unknown 
languages, while another is given the ability to interpret what is being said. [11] It is the one and only Spirit who distributes all these gifts. He alone decides which gift each person should have.

He then spoke at length about the relationship between a lack of faith and a dearth of experiences of the Holy Spirit's "gifts" during services at Agallia. It seemed clear that he had become concerned about the infrequency with which spiritual gifts such as those mentioned in the verses from 2 Corinthians were received. Other congregants shared his concern: at least one church elder, whom I interviewed around this time, expressed similar worries. Pastor Peter suggested that certain measures could be taken to "rectify the situation." These steps included "giving and praying," as well as "having faith." If congregants were to apply themselves, Pastor Peter suggested, they would be "rewarded." He intimated that a correlation existed between a lack of faith and a lack of positive material and spiritual changes in congregants' lives. If congregants had more faith, he suggested, direct experiences of spiritual gifts would follow. Congregants could be brought closer to God and their faith strengthened through prayer, but also through giving. (During a previous sermon on tithes in March, Pastor Peter repeatedly stressed that "losing on earth means gaining in heaven." But giving could also bring about material changes in peoples' lives: "give," Pastor Peter said, "and you will receive.")

Pastor Peter then spoke about a prophecy that had been made at a "global Apostolic-Prophetic conference" that he and a couple of elders had attended in Durban the previous year. The conference, hosted by the Deo Gloria Family Church (2015), ${ }^{2}$ had as its aim "to see people enter into a new dimension of God's presence and revelation for the future." According to the prophecy, members of Agallia "already reside[d] in the Kingdom of God." Pastor Peter referred to this prophecy quite often, and repeatedly emphasised the need for the congregants to "take the land, because the title deed has been given to us" and "our people have suffered enough." From previous interviews, I knew that there was a general consensus among the church's elders that Agallia's congregants were suffering inordinately "because the Enemy is also present in the Kingdom." To combat the "Enemy," whom they identified as Satan, Pastor Peter now instructed the congregants to be ever vigilant and to wear "God's suit of armour" when engaging in spiritual warfare.

To emphasise just how important direct experiences of spiritual gifts were, Pastor Peter also talked about the nature of knowledge, and how "true" knowledge could only result from direct experience of the Holy Spirit. Here he mentioned his own experience of having driven demons out of people. In common with many Pentecostal Christians, then, for Pastor Peter being a successful Christian meant having direct experience of the Holy Spirit.

Against this background, this paper examines the conspicuous absence of the gifts of the Spirit during services at Agallia Ministries, and pays specific attention to Pastor Peter's attempts to facilitate and engender these experiences among congregants: to render the invisible visible and the intangible tangible. Can this particular ethnographic example shed new light on the ways in which pastors attempt to shape churchgoers' perceptions of the world, their place in it, as well as how experiences of marginalisation and suffering relate to spirits (and their absence) that are understood to mediate between heaven and earth? I answer these questions by employing a theoretical framework that allows for religious experiences to be understood on their own terms. I pay attention to the ways in which believers initiate and employ disciplinary practices or technologies of self, such as fasting, in an attempt to achieve spiritual and religious efficacy. I focus on the symbolic and instrumental nature of religious ritual and the conditions under which it is produced and enacted. I argue that sermons provide a platform for the initiation of disciplinary practices and technologies of the self that, to varying degrees of success, enable spiritual selffashioning aimed at combating the effects of discrimination and marginalisation routinely experienced by (gay) members of Agallia. 


\section{Setting the scene}

Agallia (from the Greek "to be happy") was founded in the erstwhile Verwoerdburg, today's Centurion, a suburb on the southern outskirts of Pretoria (Tshwane), just after South Africa's democratic transition. Founding members consisted of around five men, all from Charismatic Christian backgrounds, who shared a need for a Charismatic church that catered to gay Afrikaansspeaking Christians. Like the Hope and Unity Metropolitan Community Church in Johannesburg (Reid 2010), Agallia made most of the constitutional and legislative changes that accompanied democracy and employed Pentecostal rhetoric, style and rituals to provide a counter-narrative to claims that homosexuality was un-Christian and/or morally abhorrent, and to create space for the development of an integrated identity for gay Christians in a South African context.

Services were initially held in a scout hall in Verwoerdburg. As the congregation expanded and contracted, and its means and needs changed over time, it moved a couple of times. The first move was to a small chapel in Irene, another suburb on the southern outskirts of Pretoria, and the second to an office complex in Centurion. Finally, around the turn of the new millennium, the congregation moved to a community centre in Silverton, in the north-east of Pretoria, where services were attended by a small but dedicated congregation of about 30 members every Sunday evening. I have been doing ethnographic work in this setting since October 2013. This includes regularly attending services as well as interviewing Pastor Peter and congregants in a variety of settings.

Silverton is a semi-industrial suburb. It is by no means a wealthy neighbourhood and neither are the majority of church members. Most earn less than R 6000 (around US\$365) per month and several get by on little or no income at all. Some have been destitute for extended periods of time. Quite a few currently experience, or have experienced, poor health mainly as a result of the HIV and Aids epidemic that has affected South Africa for the last thirty years. The life histories of two young men, both church members, illustrate the precarious position of some congregants very well. As teenagers, both were ostracised after their parents became aware of their homosexuality. Left destitute, both resorted to transactional sex in order to secure the money, shelter and food necessary for survival. Neither was in a position to negotiate condom usage. Both became HIV positive. Both developed drug addictions and both ended up sleeping rough on the streets of Pretoria. Although their positions have markedly improved since joining the church, as both were helped to secure employment and access to antiretroviral therapy as well as social networks and social capital, it is understandable that many church members do not see their own situations drastically improving in the immediate future. ${ }^{3}$ One congregant, Kat, who has been in and out of work for the last year, poignantly summarised this kind of frustration by exclaiming: "We are constantly told that we live in the Promised Land, but please can we just get on with it!"

The recreational centre in which services were held in Silverton was a multi-purpose complex, owned and operated by the city council. At the time of my research, the building was relatively dilapidated. It frequently sported broken windows, water-damaged ceilings and run-down or broken fixtures. On Friday and Saturday evenings, the hall was rented out for functions ranging from weddings to parties. The result was that the hall could be very dirty on Sundays with the smell of alcohol hanging thick in the air.

Pastor Peter, who has served as pastor for the last decade, received his training at the Apostolic Faith Mission (AFM), but was not ordained there because of his sexuality. As a result of his training, services took a particular form, common in many Pentecostal churches including the AFM. Generally, most of the service was dedicated to praise and worship, presided over by a music ministry, ${ }^{4}$ followed by a short sermon, with coffee and tea served thereafter. In many other Pentecostal churches, the first two phases of sermons are regularly punctuated by congregants' direct experiences of spiritual gifts. ${ }^{5}$ However, I soon became aware that this was not the case at Agallia. 


\section{Pentecostal Charismatic Churches and mediation}

Direct experiences of gifts of the Holy Spirit stand central to the ways in which most Pentecostal Christians mediate divine power and construct transcendental relationships. In Pentecostal Charismatic Churches (PCCs), signs of presence are most commonly associated with experiences of the Holy Spirit. Although "PCCs differ widely in terms of their practices and the emphases they place on ecstatic experiences" (van Wyk 2014, 40), Pentecostalism forms part of a spirituality that emphasises the direct experience of God. "Gifts of the Holy Spirit," described by Paul in the first letter to the Corinthians, include: speaking in tongues, being slain in the spirit, divine healing and prophecy (Maxwell 2006, 7-8; Luhrmann 2012, 13-14). Most Pentecostals, like other Charismatic churches, encourage the use of these spiritual gifts and, to some extent at least, measure their success by the physical manifestation thereof. Indeed, some even contend that a person is not "born again" until s/he has personally experienced spiritual gifts, most commonly by speaking in tongues.

The mediation of divine power is a central concern in the anthropology of Christianity (Cannell 2006, 17-18; Engelke 2007, 9-14). In some places in the world, Christians find the mediation less problematic than in others. Mediation can be especially challenging in PCCs that openly adopt the prosperity gospel (van Wyk 2014, 40-41; Birman and Lehmann 1999, 154-156). Some scholars have argued that tithing can work to permeate the boundaries between material and immaterial and allow for believers to transact more directly with God (see, for instance, Bialecki 2008). Religious rituals, such as services, can also serve to bind his presence (Orsi 2005, 74, 92) and to discipline bodies by employing techniques for rendering the sacred corporeally present (Asad 1993). Moreover, Christian rituals such as services "provide us with a fruitful set of problematics to explore, particularly when such rituals explicitly raise questions of meaningfulness and the contested, partial ways in which meanings can emerge in interaction" (Engelke and Tomlinson $2006,6)$. Yet Ilana van Wyk $(2014,28,234)$ notes that the content of sermons has remained largely overlooked in dominant anthropological accounts of Pentecostalism. Church clergy and their influence on churchgoers' perceptions of the world have similarly remained largely invisible in these macro-level explanations.

Most prominent among these macro-level accounts is the Comaroffian approach (see, for example, Comaroff 2009, 17-38) to Pentecostalism, which enjoys semi-paradigmatic status. This explanatory framework links the recent appeal of Pentecostalism to the possibility of moral certitude and absolute accountability, and the promise of delivery in the here-and-now. This is related to current social and economic conditions that undermine liberal humanism, and the ways in which the metaphysical provides seemingly more meaningful ways of being in a world in which the idea that humanity can author its own destiny is eroded in many places. The Comaroffian approach turns on the changing relationship between the ways in which economic forces suffocate spirituality and how spiritual beliefs give expression to the frustrations of a neoliberal existence. In short, the appeal of Pentecostalism lies in the ways in which its doctrines, rituals and practices allow adherents to domesticate and demystify modernity in a context of marginalisation shaped by globalisation and neoliberal capitalist encroachment across the world. Such an approach is both seductive and compelling, especially in sub-Saharan Africa where the last three decades have been marked by the confluence of economic, political and epidemiological crises. But it is not without its detractors.

Ruth Marshall (2009, 26-33), for instance, questions globalisation's role in shaping Pentecostal practices, the need to explain reactions to globalisation in the register of the supernatural, the underlying assumption that Pentecostal practices represent modes of interpretation and understanding rather than action, and the notion that translation is the best way to render these practices intelligible. This last issue is of particular concern, because it implies that meanings are appropriated and (de/re)coded by anthropologists in ways that usually cannot be contested by the people who they claim to make sense of. To drive her point home, Marshall mentions the frustrations of South African Zionists (who are theologically related to Pentecostals) with the absence of the role of the Holy Spirit in dominant accounts of their history. 
In a recent ethnography of the Universal Church of the Kingdom of God in South Africa, Ilana van Wyk provides another salient critique of paradigms that link Pentecostalism to the domestication of modernity and the promise of delivery in the here-and-now. Such paradigms, she tells us, all too frequently depict adherents of PCCs as "people driven by lack and need" and reduce PCCs to institutions that merely "promise to supply marginalised people with things that are out of reach" (van Wyk 2014, 234). Moreover, she notes that "macro-level explanations work at an awkward scale" in that they present PCCs and their rituals "as both a condition for and a cipher of larger economic processes" while church members "are almost exclusively defined by their economic desires. At this scale, the epistemological, ontological and semiotic conditions" that enable members to believe becomes immaterial, as do "their cultural background and history." The result, according to van Wyk, is a "curiously flattened" (27) depiction. For van Wyk, this runs the risk of oversimplifying complex meaning-making activities in an instrumentalist fashion that tends to relegate religious beliefs to the domain of false rationalisations of material and institutional conditions and to reduce people to non-spiritual beings.

An alternative explanatory framework is to be found in a Foucauldian approach, favoured by scholars such as Marshall (2009, 45-50) and Joel Robbins (2004, 216-218). In this framework, belief as it relates to Pentecostalism (or the "born-again project") constitutes the dimension of subjectivity that finds its expression through the possibility of action — of beginning anew. The production of subjectivity, or subjectivation, is a complex process that involves what Foucault $(1997,266)$ calls one's "relation to oneself," by which is meant the work of the self on the self to create an observant and ethical person. Though agentive, this process is embedded in relations of power in that it is dependent on the arrangement of cultural schemas imposed on the individual from outside. In Pentecostal projects, cultural schemas typically involve the combination of doctrinal, institutional and discursive forms (Marshall 2009, 46). This approach also has its detractors. Harri Englund (2007, 482-483), for example, notes that the Foucauldian framework is analytically problematic because it cannot hope to fully comprehend the ways in which engagements "with the world produce relationships and events that no cultural scheme can govern." Yet Foucault's analysis of the kind of self-forming activities involved in the production of proper moral subjects does promise to shed some light on the ways in which spiritual efficacy can be achieved.

Unpacking Pentecostalism in a way that is both scholastically responsible and accountable is clearly heavily contested. How, then, are we to make sense of attempts to render the supernatural real and experienced? Not only to suspend disbelief, but to equate it to the false and the unthinking (to see the world as it is, but to experience it as it should be)? This begs yet another question: how do we go about trying to make sense of Pentecostal projects in a way that does not give short shrift to epistemological, ontological and semiotic conditions that enable belief while also taking seriously the effects of large-scale social and economic changes? Van Wyk and Englund provide some clues in that they advocate a return to the local. They suggest that anthropologists turn their attention to the ways in which people believe they are situated in the world (to take the ontological turn). Englund (2007, 482-483) suggests employing the ethnographic approach, thus showing that materiality cannot be severed from symbolic and spiritual dimensions and that religious experiences and choices are "informed by what people in their particular circumstances consider to be symbolically and morally compelling." Van Wyk $(2014,234)$, in turn, notes that the rituals and conditions that enable members of PCCs "to believe in the existence of spirits and their material efficacy," as well as "the content of sermons" and "the ways in which local people" talk about and talk in PCCs, "have remained largely overlooked." Attention to these issues, van Wyk shows, enables us to develop nuanced understandings of adherents' participation in church rituals and of what they think of their blessings.

For Susan Harding $(2000,29,37)$, sermons are culturally productive rituals. They are sites in which communities are recast and resituated in history. They condition the linguistic structures to which people script their daily lives. A mode of interpretation is enacted through formal oration in 
a clear ritual format. Attention to the details and nuances of sermons might allow us a window into how, to what ends, and how successfully a pastor attempts to insinuate his mode of interpretation in the minds of his congregants.

\section{Great expectations}

I only witnessed spiritual gifts being received once during my first 10 months of regularly attending services at Agallia. This happened in February 2014 when the sermon was presided over by a visiting pastor from Boksburg, Prophet J. The main reason for Prophet J.'s visit was to support Pastor Peter, who was the only pastor at Agallia apart from holding down a fulltime job during the week. Prophet J. said that "That old idea that the pastor does everything is rubbish." He continued by saying that "the fivefold ministry ${ }^{6}$ exists to create opportunities to allow that the work gets done." He warned against "division" which, he said, "is the work of the Enemy." Prophet J. then segued into a faith healing session. ${ }^{7} \mathrm{He}$ made it clear that all diseases come from the devil and that God sometimes allows believers to become ill because "He makes you fit through pain." He urged congregants to be strong and asked whether anyone present suffered from an ailment that they would like healed. Gertie, a relatively young but long-time congregant, came forward. The pastor laid his hands on her stomach, the source of the pain, prayed and elaborately drew the disease out, after which she fainted.

Only one other instance of spiritual gifts being received - a very similar case of faith healing - occurred in the next couple of months that I attended services at Agallia. On this occasion, Pastor Peter called a congregant, Johnny, who was attending service for the first time in a long while due to illness, to the front of church. Pastor Peter said that Johnny, though still very ill, was able to attend the service due to the power of prayer. This was seen to be testament to the work of the Holy Spirit. Pastor Peter then asked members of the congregation to join him in laying hands on the ailing church member. Pastor Peter and the congregants who stepped forward took places in a circle around the sick church member, each putting a hand on him. Pastor Peter then prayed, beseeching God to draw out his illness and to cast the devil out. I did not see Johnny at services in the weeks that were to follow, although it was reported that he was on the mend.

The two examples above notwithstanding, I was struck by the absence of gifts of the Spirit during Agallia services. Listing ethnographic examples of expected events that never occur is no easy task. (I am no Samuel Beckett after all.) I will therefore attempt to describe only one instance, that being Easter, celebrated during the second week of April 2014. Easter is a very special day on Agallia's calendar. Pastor Peter had stated that, in terms of importance, it ranked higher even than Christmas, Jesus's death being more important than his birth. ${ }^{8}$ Every attempt was therefore made, and many church members went to extraordinary lengths, to make its celebration special. A veritable banquet was laid out on a shoestring budget. Tables were arranged in a U-shape in the hall and bedecked with tablecloths, oil-lamps, fresh fruit and hot-cross buns. The event was very well attended. Pastor Peter prayed and called upon the Holy Spirit to come down. As part of the ritual, everyone present was served some lamb and fruit juice (as a substitute for wine). Lights were dimmed and Pastor Peter sang to a captivated, enthralled audience. Members of the music ministry also performed. The whole event lasted a good few hours. The air was electric with anticipation throughout. Yet no one present received spiritual gifts. Nobody spoke in tongues. There was no faith healing. No one was slain in the spirit and not a single prophecy was made.

The conspicuous absence of experiences of spiritual gifts at events such as the one outlined above and during services piqued my interest. I discussed it with Pastor Peter and church elders who agreed that the phenomenon was due mainly to two factors. First, they observed that there had been a recent influx of new members from non-Pentecostal backgrounds who had not yet been trained to experience spiritual gifts. During a sermon in June, Pastor Peter, who had himself become worried about the infrequency with which gifts were being received, stated that it was crucial that "the ground had to be watered" before this would become the norm. 
There is evidence to suggest that the ground must indeed be watered before spiritual gifts can be received. The psychological anthropologist Tanya Luhrmann (2012, xiv, xv, xxi) writes that faith is difficult because it involves a decision to live as if a set of assertions are real, often in spite of doubt. This entails learning new ways of experiencing and assuming different attitudes towards being in the world. Disbelief has to be suspended, the "irrational" embraced and commitment sustained through a learning process that alters the experience of mind. Luhrmann argues that "people learn specific ways of attending to their minds and their emotions to find evidence of God, and that both what they attend to and how they attend changes their experience of their minds, and that as a result, they begin to experience a real, external, interacting living presence" (Luhrmann 2012, xxi).

During one of our regular lunch meetings around this time, Riaan, a church elder, confided in me that he had recently experienced an epiphany regarding spiritual gifts. He related that he had been sitting at home one day and suddenly felt as though a dark cloud had descended over the neighbourhood in which he stayed. This coincided with dogs barking ceaselessly that day and a lot of chatter on his citizens' band radio (CB Radio). "People were restless," he told me. A feeling settled on him that something was not quite right. He interpreted this as die bose [evil/wickedness] gaining ground, and castigated himself for not realising earlier that he had to pray to counteract it. "By not practicing spiritual gifts," he told me, "people forget how to use them. They then become only theoretical." As mentioned above, scholars such as Tanya Luhrmann have analysed how people can be trained to hear God's voice and to experience it as real. But a lack of training and practice only goes so far in explaining why spiritual gifts are not being received in a church that has existed for the best part of two decades and has kept, through time, a loyal if small core of members.

Second, the senior church members I spoke to were of the opinion that the state of affairs was precipitated by a lack of faith among the congregation. During the sermon in June, mentioned above, which was dedicated to spiritual gifts, Pastor Peter used the term faith in explaining why people were not seeing a material and spiritual difference in their lives. An earlier remark during a sermon on the importance of praise and worship serves to contextualise Pastor Peter's position: it is a "difficult thing," Pastor Peter said, "to have God in your life if you're not in a lekker plek [good place] in your life." In another sermon he emphasised: "We are the odd ones out. We are [the] persecuted," and in yet another that "rejection is the worst kind of wound." In such a context, it can be difficult to cultivate the faith on which relationships with the divine are constructed. If the development of these relationships is frustrated, so too are direct experiences of spiritual gifts.

The perceived efficacy of Christian rituals, such as services, frequently depends on the manipulation of words (Engelke and Tomlinson 2006, 6). But this manipulation can be very difficult, seeing that Christian doctrine is inherently paradoxical (Cannell 2006, 41, 43). Christianity is not exclusively a religion of transcendence. It is not simply about the spirit elevating itself over the flesh, but also about salvation in the here-and-now. The flesh is, therefore, an essential part of redemption, both theoretically and in lived practice. At Agallia this ambivalence is addressed by a set of seemingly contradictory propositions. During sermons, Pastor Peter frequently emphasised that "losing on earth" entailed "gaining in heaven," and that "gratitude follows hardship." Yet the key message during sermons was just as frequently that the congregation was already living in the Kingdom of God and Promised Land, that "our barns will be filled with every provision," and that "our people have suffered enough." These propositions were reconciled by the notion that "the Kingdom of God so easily loses the battle" on earth due to "a lack of discipline and obedience in our lives." As I have shown above, "empty barns" can lead to frustration and lack of hope among congregants.

This tension was resolved through attempts to reconcile body and spirit. A sermon about the "power of fasting" in May 2014 serves as prime example of this bodily fashioning. During this service, Pastor Peter said that fasting "in modern times is a very personal experience" and a ritual that allowed one "to experience closeness to God." "To fast is to sacrifice," he continued, and to be engaged in "when you are in need of God's intervention," "to appeal to God." Pastor Peter then gave instructions to members to go and fast and to return to give testimonials the following week. 
The next Sunday, congregants were called upon to testify about their experiences of fasting. A few people came forward and affirmed that they had indeed experienced positive changes in their lives. These changes were all of a material nature: one congregant received a car as gift from a family member, another found employment and a third received a raise at work. ${ }^{9}$ One church member confided that "in the current political situation, it is God" who looked after them financially. Pastor Peter agreed: "Things are not going to improve, but [if we are obedient and disciplined], God's provision will." Yet many congregants remained frustrated in material terms and therefore sceptical of the efficacy of the disciplinary practices Pastor Peter attempted to encourage. Indeed, there had been instances of congregants asking, "Why, if this stuff works," do people "continue having all these problems?"

In a context of lack, faith or belief is evidently hard to achieve and maintain, regardless of how well words are manipulated and the meaning/s of biblical passages and prophecies interpreted. In a sense, the absence of spiritual gifts during services was offset or alleviated by the type of gains that resulted from the ways in which Pastor Peter's sermons gave shape to church members' understandings of the world outside of church and their blessings inside of it. This form of ethical self-fashioning might have been a precursor to spiritual gifts during services in that it helped construct or reinforce the belief and trust necessary to experience and receive such gifts. Pastor Peter's attempts to show that practices such as tithing, fasting and praying lead to blessings and miracles, worked to "water the soil" and prepared it for proper exchange relationships with God — and ultimately direct experiences of the Holy Spirit.

\section{Constructing trust}

In the anthropology of religion, a number of scholars have suggested that we should dispel with the word belief because of its specifically western theological freight (Cannell 2006; Smith 1977) and rather focus our attentions on trust. Trust and entrusting are key concepts, often overlooked in many anthropological accounts of Pentecostalism, with scholars frequently disregarding the role of suspicion and doubt in the lives of Pentecostal Christians. However, when livelihoods are precarious and people's lives are characterised by uncertainty, distrust and suspicion frequently become the norm and trust the exception (Englund 2007, 479).

Understanding the ways in which trust and entrusting are constructed, contested and/or denied during services at Agallia is therefore crucially important. But so too is an appreciation of the articulation of these attempts with congregants' lived experiences outside of church. The first step to achieve this seems to me to unpack the relationship - if not direct correlation - between church members' near constant marginalisation and the infrequency, or particular circumstances, under which they receive gifts of the Spirit. People's everyday lives and material realities, as the Comaroffian approach reminds us, give shape to, or at the very least articulate with, their experiences of the metaphysical. Perhaps most importantly in this regard, many churchgoers do not seem to have any real expectation of their situation improving drastically in the immediate future. Hylton White (2013, 139-145) shows that personal ties can be, and often are, dependent on impersonal ones and that these, in turn, are organised by structures of political economy. At Agallia, ties with the invisible found expression in a dearth of experience of spiritual gifts during services, and were clearly shaped by congregants' social and economic marginalisation.

However, in order to avoid "curiously flattened" descriptions, it is important that we do not lose sight of the ways in which pastors and the content of sermons influence how congregants perceive the world, their place in it and their relationships with the invisible. It is therefore important that we take a second step and focus, as van Wyk and Englund urge us, on the ontological. We have already seen how attempts were made during Agallia services to resolve the tension between divine mediation and salvation in the here-and-now. Spiritual warfare was an important part of this process. One whole sermon was dedicated to "God's suit of armour" and how it is to be worn in the fight against the devil or "The Enemy." We have also seen how this war was used to make 
sense of suffering and marginalisation. Spiritual warfare is framed as a difficult, arduous and near constant exercise. "God's suit of armour," though effective, was unwieldy and demanded a lot from congregants. Indeed, services were littered with references to the power of prayer and fasting, and the importance of tithing, discipline and obedience. Yet "the Kingdom of God" sometimes "easily loses the battle," because "of a lack of discipline and obedience" in the face of The Enemy's onslaught. Such explanations accounted for religious back-sliding and frustration experienced and articulated by congregants.

It also seems evident that a purely Foucauldian framework struggles, in this instance at least, to come to terms fully with the ways in which engagements with local material realities affected the experience of faith among members of Agallia during the Sunday services described above. Put differently, an analysis of the ways in which doctrinal, institutional and discursive forms combined to shape cultural schemas is not likely to explain in full why devoted members of a small Pentecostal church in the industrial north-east of Pretoria so infrequently received spiritual gifts. However, an analysis of the processes involved in ethical self-fashioning does enable us to better come to terms with the kind of ethical work engaged in to transform church members into moral subjects who are able to reconcile the contradictory propositions in Christian doctrine outlined above. In this context, fasting could be read as a disciplinary practice, or technology of self, meant to shape religious subjectivities. Fasting therefore helps give shape to moral dispositions; and sermons, during which fasting is initiated, constitute forms of ritual discourse that guide religious self-fashioning (Asad 1993, 125-135).

In a sense, the way in which congregants reported receiving material gifts subsequent to fasting outside of church formed part of a rehearsal regimen that preceded spiritual gifts being received during church services. Kat's desire to progress both spiritually and materially was widely shared in the congregation and represented a common theme during many of Pastor Peter's sermons when it was almost always emphasised that this progression was imminent.

Pastor Peter's visible frustration on the occasions that the church building was "polluted" were also important. When this was the case, he got visibly upset. At a deeper level, the building's polluted and decrepit state reflected, or acted as a metaphor for, the congregants' material and spiritual positions in life. During an interview he told me that "I am very frustrated when we have to go to [have services in] a dirty place." Pastor Peter was not alone in his frustration. A few of the church's more well-off congregants have in the past expressed a desire to move to a more "appropriate" building in a more affluent neighbourhood. This did not transpire, however, due partly to the fact that many of the church's more needy congregants would not be able to attend services if such a move were to take place. Religious efficacy, in the form of gifts of the Spirit being received during services, was hindered by perceptions around the polluted state of the inside of the church building. These perceptions also help to account for the fact that fasting, which takes place outside of church, seems more effective than spiritual gifts that are meant to be received inside of it. Contrary to a large body of work on Christian churches that emphasises the ways in which churches create safe and socially supportive environments, patterns of discrimination outside of church seemingly influenced worship inside of Agallia.

Counteracting the effects of discrimination and stigmatisation of congregants, especially with regards to sexuality, has long been a central part of Agallia's project. Pastor Peter relates that he himself had believed until 2001, when he first came to Agallia, that "the Lord will heal me, [that] this [homosexuality] is a thing that would heal. For many years I had believed that the Lord would heal me." This is exactly why a visiting pastor recently dedicated a whole sermon to the internalisation of stigma. He spoke about Caster Semenya, a South African athlete who recently made news headlines because she had been subjected to gender testing. He emphasised that "God knew her in her mother's womb" and suggested that the controversy around Semenya revolved around fear: "fear is the opposite of faith," he said, while "faith is love" and "drives out fear." The take-home message was that homosexuality is not unnatural and that "the day you accept your 
sexuality is the day that you praise and thank the Lord for making you exactly like you are." The reception was overwhelming.

\section{The fire falls (at last)}

Then, on two consecutive Sundays (May 17 and 24, 2015), things changed dramatically. I sensed a difference right from the outset of both services. The music ministry seemed more vibrant than usual. They played longer and with more gusto than I had become accustomed to. Additional instruments (a guitar and keyboard) and songs had been added to their repertoire, and there were more backup singers. There was also a new music ministry leader. Both services lasted longer than the usual hour or so that I had become accustomed to (one lasted two hours and the other an hour and three quarters). All of this seemed to have an effect on the congregation's mood. And during both services spiritual gifts were experienced: on each occasion a congregant was slain in the spirit. Both times Pastor Peter called on the congregation to raise their hands or come forward if they wanted to "give" themselves "to God." When two people did, one during each service, elders or members of the music ministry positioned themselves behind the congregant. Pastor Peter then prayed over them and touched their foreheads, after which they fell backwards into the arms of the church members behind them and were laid down on the floor.

A couple of weeks later, I asked Pastor Peter about the role that the music ministry's newfound vigour and vibrancy might have played in the direct experiences of spiritual gifts at Agallia. He answered that "at the end of the day it is about the Kingdom. And as we know, scripture tells us that God is the cultivator of the vineyard." Riaan, an elder with whom I had regular lunch meetings, elaborated:

\footnotetext{
You have to create space for the Holy Spirit to work. When you only play DVDs [that people sing along to, as had frequently been the case] ... you just follow it. But if you have a voorsanger [someone who leads the music ministry in song] and a music ministry singing and the voorsanger is led by the Holy Spirit, then he takes the next steps in the way he is led and that has the effect that a forum is created for the Holy Spirit to work among the people, because it is not just the formal singing of a song and the words appear [on a screen] and that type of stuff. This is now more of a reality in which the Holy Spirit can be present and work. Not that this is impossible when you play DVDs, but this just creates a better ... atmosphere or a better opportunity for it to work, because people are more focussed, more finely tuned. And you experience it better than when you formally play a DVD and you sing and the music levels stay the same ... [I]f [on the other hand] there is a music team in front that play[s] on a keyboard and sing[s] ... they can sing louder and softer and they can repeat ... and that kind of thing is actually really important in a Pentecostal movement. The guy who plays the keyboard listens and reacts to the direction he feels things are going in ... [W] hen you have a music ministry ... guided by the Spirit ... then people become more aware of 'What am I singing? What am I saying? What am I asking?' And then they become more involved. And that ... leaves room for the Holy Spirit to work.
}

Put slightly differently, the music ministry helped create conditions conducive to congregants experiencing the Holy Spirit as a tangible presence. It was seen to focus and orientate the mind and to teach congregants how to listen attentively and to hear properly. This, combined with technologies of self and disciplinary practices, such as the fasting, giving and spiritual warfare initiated by Pastor Peter, and complemented by efforts to counteract internalised stigma, served to construct and cultivate the faith/trust necessary to mediate presence successfully and to have more frequent direct experiences of spiritual gifts. It is perhaps worth mentioning that these instances happened just after the city council had replaced the broken windows and painted the ceilings in the building — in so doing alleviating its perceived polluted state and further facilitating the likelihood of direct experiences of spiritual gifts.

\section{Conclusion}

Thinking through the implications of the infrequency with which spiritual gifts have been received at Agallia allows us to accord importance and weight to the spiritual dimension of Pentecostalism. 
In a sense, it may show how spiritual experience articulates with social and economic conditions in a world where the idea that humanity can author its own destiny no longer makes much sense for many people in many places. In another sense, it could also illustrate how Pentecostal practice can serve as the "symbolic resistance of the marginalised" (Meyer 2004, 464). This might be particularly relevant to the South African situation where unemployment has soared due to the recent global economic crisis, where inequality has risen to an unheard of level, ${ }^{10}$ where labour has been disproportionally informalised over the last couple of decades, where the HIV and Aids epidemic has made the lives of people in resource-limited communities very hard indeed, and where there has been a recent upsurge in discrimination (including hate-crimes) against homosexuals. But it also points to the need for a "somewhat weaker, less deterministic formulation," not altogether different from Isak Niehaus's ideas around witchcraft in the South African lowveld. That is to say, one that simply treats "the sorts of frustrated expectations, social relations, and misfortunes encountered in contemporary South Africa as one possible context" (Niehaus 2013, 5) for the particular shapes of Pentecostal practices and their appeal, without positing a direct causal relationship. In the preceding pages we have seen how the social and economic marginalisation of churchgoers at a small PCC in Pretoria, shaped by the confluences of homosexuality, poverty and stigmatisation, correlate with very infrequent experiences of gifts of the Spirit during services. We have also seen how ideas around contagion influence the ways in which frustrations regarding marginalisation and a lack of religious efficacy are expressed. And we have seen how certain disciplinary practices are understood to bring about material gains.

But this is only part of the story. We also need to pay close attention to the content of sermons and the people who attend them if we are not to give short shrift to the epistemological, ontological and semiotic conditions that enable belief. This allows us to show how people's religious choices and experiences cannot simply be reduced to occult economies in which they deploy magical means for material ends. Attention to issues such as the content of sermons and the ways in which meaning is produced allows us not only to depict people's religious choices and experiences in higher resolution, but also to show how local factors articulate with large structural forces to shape these choices and experiences. Indeed, the disciplinary practices mentioned above are not understood as merely bringing about material gain. They also form part of a process of ethical self-fashioning meant to construct religious selves and to create obedient wills. Moreover, they might very well constitute a rehearsal regimen understood to precede spiritual gifts being received during services at Agallia. The sermons during which these disciplinary practices were initiated, in turn, could be read as forms of ritual discourse that guide the re/structuring of religious selves.

A focus on the content of sermons, furthermore, allows us to develop understandings of how attempts are made in PCCs to address a paradox inherent to Christianity: reconciling ideas around the elevation of the spirit over the flesh with notions about the flesh as an essential part of redemption, both theoretically and in lived practice. These attempts also shed some light on the complex ways in which local factors articulate with large structural forces to shape trust and entrusting — or lack thereof — in the efficacy of spirits, understood to mediate between heaven and earth and to aid believers in the here-and-now, and to make better sense of the nuances of particular religious experiences and choices. We have seen how Pastor Peter's sermons work to reconcile contradictory propositions in Christianity (related to the flesh and the spirit), and as discursive acts meant to aid in the achievement of religious efficacy. We have also seen, however, how these attempts are not always successful, and how some congregants are at times left frustrated, despite Pastor Peter's best efforts.

Finally, attention to local PCCs attended by marginalised adherents allows us to close the gap in the literature in African studies, identified by Englund (2007), caused by too great a focus on prosperity gospels and middle classes. The fieldwork discussed in this paper draws attention to the degree to which some gay, white South African men have been subjected to the dual afflictions of HIV and joblessness. In so doing it provides a counter narrative to commonly held public 
perceptions surrounding this demographic. What is more, it shows how Pentecostal idioms, rhetoric and rituals can provide the means with which to attempt to counteract these forms of marginalisation. Importantly, however, it also points to the limits of directed religious action in the context of political, economic and epidemiological crises.

\section{Acknowledgements}

This research was made possible by the University of Pretoria's Capital Cities Project and the Mellon Foundation. Previous versions were presented at the Southern African Historical Society conference in Stellenbosch in 2015 and as part of the University of Pretoria's Department of Historical and Heritage Studies seminar series. I wish to thank the following colleagues for their input: Pierre Brouard, Catherine Burns, Mary Crewe, Norman Duncan, Lizé Kriel, Giselle Lowe, Alan Mabin, Fraser McNeill, Alois Mlambo, Isak Niehaus, Nisa Paleker, Theodore Powers, Pierre Reyneke, Neil Roos, John Sharp, Thula Simpson, Jonathan Stadler, Hennie Stander, Charles van Onselen, Ilana van Wyk and two anonymous reviewers.

\section{Notes}

1. In cases where I have been given explicit permission to do so, I have made use of real names. In other instances I have employed pseudonyms.

2. Agallia Ministries has ties to a series of churches that cater to the needs of gay Christians. These include Agape Revelation Church in Boksburg, the Reforming Church in Pretoria and Deo Gloria Family Church in Durban. Pastors/ministers from these churches regularly give guest sermons at Agallia and Pastor Peter reciprocates. Pastor Peter and some congregants also attend events, such as the one outlined above, organised by these churches. Pastor Peter recently presided over the wedding of a minister of one of these churches.

3. Benjamin Roberts and Vasu Reddy's (2008) review of attitudes towards homosexuality, derived from the South African Social Attitudes Survey, provides evidence that South African society remains largely prejudiced despite guaranteed constitutional protection. This suggests that while a rights-based model governs claims to citizenship in the country, attitudinal changes do not necessarily correlate with changes in rights. A complex interplay of individual, social and structural forces, including the dominance of patriarchy, heteronormativity and institutionalised (state, civil society and faith-based) prejudice, informs attitudes and practices. In 2003, the Joint Working Group, a national network of LGBTI organisations in South Africa, set out to investigate several under-researched issues having an impact on lesbian and gay people. The studies were conducted in the provinces of Gauteng and KwaZulu Natal (KZN) by OUT. Findings included that more than one third of the black and about half of the white gay men and lesbian women interviewed experienced discrimination from religious organisations. What is more, $15 \%$ of the participants in Gauteng and $9 \%$ in KZN had been refused a job opportunity on the basis of their sexual orientation.

4. The changing nature and perceptions of the music ministry play a central role in the eventual achievement of spiritual efficacy. When I started attending services it was comparatively small, rather ill-equipped and highly structured (almost scripted). As we shall see, additions and changes to the music ministry correlate with spiritual gifts being received more frequently.

5. According to Burger and Nel $(2008,145)$, "In the Pentecostal movement the personal experience of the baptism with the Holy Spirit has always been a standard of spiritual progress and blessing in the Church."

6. The fivefold ministry is based on the charismatic and evangelical belief that the offices mentioned in Ephesians 4: 11, namely those of apostle, prophet, evangelist, pastor (or "shepherd") and teacher, are valid offices in the church today.

7. Faith healing has always played an important role in the AFM. According to Burger and Nel, the AFM "held to definite theological principles concerning divine healing ... The basic point of departure was that all sickness was initiated by Satan." Healing the sick was seen as God's will. However, "heavy emphasis was laid on the individual's faith. When people were prayed for but did not get healed, imperfect faith was blamed. Divine healing has always attracted people and this was probably the decisive factor that persuaded people to set aside their objections and prejudices and to attend the services of the AFM" (Burger and Nel 2008, 56).

8. A church elder explained: 'Jesus' death on the cross reconciled us with God, it is more important than His birth."

9. It is important to note that Agallia, like the AFM, does not subscribe to the prosperity gospel. Burger and $\mathrm{Nel}(2008,374)$ write that the AFM objects to the prosperity gospel because in "this theology man is 
made central and his faith makes him sovereign over God. It is a subtle evangelical humanism, in which the human element in religion is focused on in such a way as to virtually deify a man."

10. According to a recent Oxfam report on global inequality (Seery and Caistor Arendar 2014), South Africa ranks as the most unequal society in the world, with the two richest South Africans possessing the same monetary wealth as the poorest $50 \%$ of the population.

\section{References}

Asad, T. 1993. Genealogies of Religion: Discipline and Reasons of Power in Christianity and Islam. Baltimore: Johns Hopkins University Press.

Bialecki, J. 2008. "Between Stewardship and Sacrifice: Agency and Economy in a Southern California Charismatic Church." Journal of the Royal Anthropological Institute 14 (2): 372-390.

Birman, P., and D. Lehmann. 1999. "Religion and the Media in a Battle for Ideological Hegemony: The Universal Church of the Kingdom of God and TV Globo in Brazil." Bulletin of Latin American Research 18 (2): $145-164$.

Burger, I., and M. Nel. 2008. The Fire Falls in Africa: A History of the Apostolic Faith Mission in South Africa. A Centennial Edition 1908-2008. Vereeniging: Christian Art Publishers.

Cannell, F. 2006. The Anthropology of Christianity. Durham: Duke University Press.

Comaroff, J. 2009. "The Politics of Conviction: Faith on the Neo-Liberal Frontier." Social Analysis 53 (1): $17-38$.

Deo Gloria Family Church. 2015. “About Us: Conferences.” Deo Gloria Family Church. Accessed May 2015. http://www.deogloria.org/about/

Engelke, M. 2007. A Problem of Presence: Beyond Scripture in an African Church. Berkeley: University of California Press.

Engelke, M., and M. Tomlinson, eds. 2006. The Limits of Meaning: Case Studies in the Anthropology of Christianity. New York: Berghahn Books.

Englund, H. 2007. "Pentecostalism beyond Belief: Trust and Democracy in a Malawian Township." Africa 77 (4): 477-499.

Foucault, M. 1997. Ethics: Subjectivity and Truth. New York: The New Press.

Harding, S.F. 2000. The Book of Jerry Falwell: Fundamentalist Language and Politics. Princeton: Princeton University Press.

Luhrmann, T.M. 2012. When God Talks Back: Understanding the American Evangelical Relationship with God. New York: Alfred A. Knopf.

Marshall, R. 2009. Political Spiritualities: The Pentecostal Revolution in Nigeria. Chicago: University of Chicago Press.

Maxwell, D. 2006. African Gifts of the Spirit: Pentecostalism and the Rise of a Zimbabwean Transnational Religious Movement. Oxford: James Currey.

Meyer, B. 2004. "Christianity in Africa: From African Independent to Pentecostal-Charismatic Churches." Annual Review of Anthropology, no. 33: 447-474.

Niehaus, I.A. 2013. Witchcraft and a Life in the New South Africa. Cambridge: Cambridge University Press.

NLT (Holy Bible: New Living Translation). 2007. Carol Stream: Tyndale House Publishers.

Orsi, R.A. 2005. Between Heaven and Earth: The Religious Worlds People Make and the Scholars who Study Them. Princeton: Princeton University Press.

Reid, G. 2010. Above the Skyline: Reverend Tsietsi Thandekiso and the Founding of an African Gay Church. Pretoria: Unisa Press.

Robbins, J. 2004. Becoming Sinners: Christianity and Moral Torment in a Papua New Guinea Society. Berkeley: University of California Press.

Roberts, B., and V. Reddy. 2008. "Pride and Prejudice: Public Attitudes toward Homosexuality." HSRC Review 6 (4): 9-11.

Seery, E., and A. Caistor Arendar. 2014. "Even it Up: Time to End Extreme Inequality." Oxfam International. http://www.oxfam.org/sites/www.oxfam.org/files/file_attachments/cr-even-it-up-extreme-inequality291014-en.pdf

Smith, W.C. 1977. Belief and History. Charlottesville: University of Virginia Press.

van Wyk, I. 2014. The Universal Church of the Kingdom of God in South Africa: A Church of Strangers. Cambridge: Cambridge University Press.

White, H. 2013. "Spirit and Society: In Defence of a Critical Anthropology of Religious Life." Anthropology Southern Africa 36 (3\&4): 139-145. 